thirds rule in the Senate, the "executive-legislative" (or congressionalpresidential) agreement. But it is reasonably inferable that one major reason is that key senators might strongly object.

When for the fiscal year 1979 the foreign relations institutions of the United States were "reauthorized" (in a way that some other ministries are not), the Report of the Committee of Conference, in dealing with the tightening amendments to the Case-Zablocki Act, contained this:

The Senate amendment expressed the sense of the Senate that the President should have prior consultations with the Senate Foreign Relations Committee as to whether particular agreements between the United States and other countries should be a treaty or an Executive agreement [emphasis added].

The House bill did not contain a comparable provision.

The conference substitute contains no provision on this issue.?

The fact that the Senate made the effort may show that something more than reporting "all-presidential" executive agreements is in play. The executive could probably make some pretty good bargains with the committee as to which way to go in regard to particular types of international agreements.

At least the sense resolution gives the executive a basis for frank discussion of which way to go, which may defuse potentially heated objections in the Senate and, if well done, ensure a majority of the Senate will more often approve a legislative-executive agreement as an alternative to a Senate-consented (by two-thirds) "treaty." In time this new dimension for consultation might even be expanded to include the House Committee on International Relations.

An institutionalized structure of the sort envisaged also has the virtue of removing executive-legislative collaboration in this field from the rulewhatever it is-of Buckley v. Valeo, ${ }^{8}$ about separation of powers.

A collaborative evolutionary growth to diminish the disadvantages of an archaic, perhaps even originally unfortunate, arrangement would avoid, also, the great problems inherent in changing the text of the Constitution by formal amendment, particularly in times when talk of an "open convention" to deal with proposed ceilings on the taxing power is having a chilling effect.

Covex T. Oliven

\title{
Termination of the USSR's Treaty Right of INTERVENTION IN IRAN
}

Political developments in Iran have renewed attention on a Soviet-Iranian treaty ${ }^{x}$ purporting to grant the Soviet Union a discretionary right of military

7 Joint Explanation of the Committee of Conference, H. Conf. Rep. No. 95-1535, 95th Cong., 2d Sess. 64, reprinted in [1978] U.S. Code Cong. \& AD. NEws 2480, 2505.

8 "The Federal Elections Commission case," 424 U.S. 1 (1976), states that as Congress cannot "manage," it cannot be authorized by statute to appoint a congressional quota of managers to the commission.

1 Treaty of Friendship between Persia and the Russian Socialist Federal Republic, 
intervention in Iran, should Moscow conclude that certain interests are menaced." Iran had long chafed under the treaty.

[I]n 1958 and 1959, the Shah had sought to secure Soviet agreement to the annulment of the same articles. ... [T] to discuss the question with Iran but only in connection with Soviet demands at the time that Iran get out of the U.S.-sponsored Baghdad Pact, refrain from signing a military agreement with the United States, and conclude a new non-aggression treaty with the Soviet Union. None of these took place and the Soviets from time to time have pointedly emphasized the continued validity of the 1921 treaty. ${ }^{3}$

On November 5, 1979, authorities in Iran announced the abrogation of the two articles in the treaty providing for Soviet intervention. To date, the USSR has not indicated its response. ${ }^{4}$

It takes at least two to make valid treaties and two may terminate them lawfully; but a treaty may also be terminated unilaterally in the event of invalidity or breach, among other reasons. Comments in the United States and Western Europe have assumed the continuing validity of the treaty and hence the need to contemplate the possibility of a lawful Soviet intervention in Iran. Such an assumption can only stiffen Soviet resistance to the loss of a most attractive political option. The assumption of the treaty's validity and the prospective diplomatic acquiescence it has generated may be too hasty. The purport and validity of the treaty are open to a number of questions. Its original terms were restrictively amended in an exchange ot notes before ratification; hence, if the treaty is properly interpreted, there may be no authorization of intervention in the current context. Moreover, some fundamental conditions that the treaty contemplated have changed. Most significant, subsequent changes in international law may have rendered parts of the treaty void, so that an intervention on its purported authority would be an act of aggression in violation of the United Nations Charter. All of these grounds may allow Iran to terminate key provisions of the treaty, despite Soviet objections.

The "Treaty of Friendship" was signed in Moscow on February 26, 1921. In broad language, it nullified "the whole body of treaties and conventions concluded with Iran by the Tsarist Government," s as well as those con-

signed at Moscow, February 26, 1921, 9 LNTS 384. LNTS published the treaty in Farsi and Russian, both original and equally authentic languages according to Article 25, and, in addition, published French and English translations. The treaty refers to Iran as Persia and to the USSR as the Russian Socialist Federal Republic and Russia. For purposes of consistency and clarity, this comment will use the name "Iran" for all references to Persia and "USSR" for all references to the Russian Socialist Federal Republic or Russia.

2 Art. 6 , id. at 403.

${ }^{3}$ Sovier World Outlook, November 15, 1979, at 2 (published by Advanced International Studies Institute, University of Miami).

4 lbid.

"Art. 1, Treaty of Friendship, supra note 1, at 401. 
cluded between the Tsarist Government and other states with respect to Iran. The treaty purported to repudiate the sphere of influence strategies that had been part of tsarist policy. ${ }^{6}$ Tsarist economic imperialism was lenounced, ${ }^{7}$ and the USSR terminated its territorial concessions and consular capitulations in Iran, ${ }^{8}$ while Iran promised not to cede them to a third power. $^{9}$ Russian religious missions were to be suspended and their property given to Iran. ${ }^{10}$ But the treaty also reaffirmed some of the key aspects of the ancien régime. The boundaries that had been established by a treaty in $1881^{11}$ were affirmed; certain sectors seized after that date were retroceded to Iran, while Iran renounced claim to other territories claimed by Russia. 1: Thus, Russian reduction of Iranian territory in the 19th century by almost a third was largely confirmed; in addition, a concession for Caspian Sea fishing in favor of the USSR was to be executed..$^{13}$

Article 4 of the treaty expressed a mutual commitment "to abstain from any intervention in the internal affairs of the other." Article 5 provided:

The two High Contracting Parties undertake

(1) To prohibit the formation or presence within their respective territories, of any organisations or groups of persons, irrespective of the name by which they are known, whose object is to engage in acts of hostility against Persia or Russia, or against the Allies of: Russia.

They will likewise prohibit the formation of troops or armies within their respective territories with the afore-mentioned object.

(2) Not to allow a third Party or any organisation, whatever it be called, which is hostile to the other Contracting Party, to import or to convey in transit across their countries material which can be used against the other Party.

(3) To prevent by all means in their power the presence within their territories or within the territories of their Allies of all armies or forces of a third Party in cases in which the presence of such forces would be regarded as a menace to the frontiers, interests or safety of the other Contracting Party. ${ }^{14}$

Article 6 of the Friendship Treaty provided:

If a third Party should attempt to carry out a policy of usurpation by means of armed intervention in Persia, or if such Power should desire to use Persian territory as a base of operations agaiast Russia, or if a Foreign Power should threaten the frontiers of Federal Russia or those of its Allies, and if the Persian Government should not be able to put a stop to such menace after having been once called upon to do so by Russia, Russia shall have the right to advance her troops into the

${ }^{6}$ Art. 2, id. at 401.

7 Arts. 8 and 9 , id. at 405.

${ }^{8}$ Arts. $9,10,11,12$, and $16, i d$. at $406-08 . \quad{ }^{9}$ Art. 13, id. at 407.

10 Art. 15, ibid.

11 The treaty incorrectly referred to the treaty of 1881 as a Boundary Commission, and the Persian Government clarified this matter in the exchange of notes on December 12, 1921, which is discussed below. For the texts, see 9 LNTS 411-13.

12 Art. 3, Treaty of Friendship, supra note 1, at 403.

${ }^{13}$ Art. 14, id. at 407.

14 Id. at 403 . 
Persian interior for the purpose of carrying out the military operations necessary for its defence. Russia undertakes, however, to withdraw her troops from Persian territory as soon as the danger has been removed. ${ }^{1.5}$

Article 7 reaffirmed the principles of Article 6 and gave the USSR "the right to require the Persian Government to send away foreign subjects, in the event of their taking advantage of their engagement in the Persian navy to undertake hostile action against Russia." ${ }^{10}$ But Article 7 did not augment the interventionary authority of Article 6.

Articles 5 and 6 were far-reaching, even in terms of the realpolitik of the day and, in the course of the internal ratification procedure, aroused some concern in the Persian Mejlis or Parliament. On December 12, 1921, the two Governments exchanged documents that constituted clarification and perhaps amendment of the draft treaty: The Persian Government wrote in relevant part:

The Persian Government and the Mejlis have observed that Articles 5 and 6 of the Treaty concluded between our two countries are worded vaguely; the Mejlis moreover, desires that the retrocession of Russian concessions to the Persian Government should be made without reserve or condition, and, that Article 20 should be so worded as to allow the Persian Government full powers for the transit of imports and exports. Conversations have taken place with you on these questions, and you have given explanations with regard to Articles 5 and 6 and promises concerning Articles 13 and 20 , to the effect that if the Treaty were passed by the Mejlis you would give all the assistance in your power to ensure that the two Articles in question should be revised on the lines desired by the Mejlis and the Persian Government. The Persian Government and the Mejlis are most desirous that friendly relations should be re-established between our two Governments, and that the Treaty, which is based upon the most amicable sentiments, should be concluded as soon as possible. ${ }^{17}$

The Soviet response of the same date stated in relevant part:

In reply to your letter dated 20th day of Ghows, I have the honour to inform you that Articles 5 and 6 are intended to apply only to cases in which preparations have been made for a considerable armed attack upon Russia or the Soviet Republics allied to her, by the partisans of the regime which has been overthrown or by its supporters among those foreign powers which are in a position to assist the enemies of the Workers' and Peasants' Republics and at the same time to possess themselves, by force or by underhand methods, of part of the Persian territory, thereby establishing a base of operations for any attacks-made either directly or through the counter-revolutionary forces-which they might meditate against Russia or the Soviet Republics allied to her. The Articles referred to are therefore in no sense intended to apply to verbal or written attacks directed against the Soviet Government by the various Persian groups, or even by any Russian émigrés in Persia, in so far as such attacks are generally tolerated as between neighbouring Powers animated by sentiments of mutual friendship. ${ }^{18}$

xilbid.

17 Id. at 411 .
16 Art. $7, i d$ at 405 .

is Id. at 413 . 
The precise objections of the Mejlis to the original text of Articles 5 and 6 are not expressed in the Persian statement of December .12, though the Soviet response suggests that a key issue was whether mere propaganda"verbal or written attacks"-would warrant Soviet intervention. It is quite likely that the anxieties of some members of the Mejlis went to the real core of the issue, the unilateral right of characterization of menace and intervention; the interpretation of the Persian concern voluateered in the Soviet response of December 12 indicated Soviet unwillingness to yield on its insistence of a treaty right of intervention. Despite the usual fraternalistic language, the parties were hardly in a position of power parity and the nonreciprocal character of Article 6, the heart of the agreement, raises the suspicion that this was quite an unequal treaty.

The regime that emerges from the texts of Articles 5 and 6 in the light of the clarification of December 12,1921, is complex in parts that are essentially superfluous but extraordinarily simple at its core. Article 5 establishes a pattern of reciprocal claims as between the parties: to prohibit the formation or presence of groups intending hostile acts against the other state, to prohibit transshipment by third parties with hostile intentions against the other state, and to prohibit the presence of "forces" of a third party that would be recognized "as a menace to the frontiers, interests or safety of the other Contracting Party."

Article 6, the key operative provision, is nonreciprocal It permits only the Soviet Government to intervene and to carry out military operations in Iranian territory if, in the unilateral opinion of the Soviet Government, certain broadly defined activities occur and, in the Soviet view, the Iranian Government is unable to stop the activities after having been called upon to do so by the USSR. The characterization of the activities as a menace, the conclusion that the Iranian Government is unable to stop them, and the determination that the danger has been terminated and that the USSR may then withdraw are all matters of Soviet urilateral competence.

In sum, Article 6 accords the Soviet Government a unilateral right of intervention in Iran for reasons, purposes, and durations to be determined solely by it. The conditions include seizure of territory by a "third party," desire to use territory by such a party as a "base of operations against Russia," and menace by a foreign power of frontiers of Russia and its allies. Apparently only in the final contingency must the USSR first call upon Iran to put a stop to the offending activities. For the first two contingencies, the Soviets may act without prior attempt at exhausting "local remedies." The apparent limitation of the third contingency may be quite illusory, since only the Soviet Government determines the threat and the adequacy of the Iranian response. Since Article 6 refers to third parties as well as "Foreign Powers," we may assume that the intention was to include activities by nonstate groups, not excluding those of Iranian origin. 
II.

But the terms of the treaty were revised in the ratification process. In the letter of December 12,1921, which appears as an annex to the treaty, the Soviet Government, in response to objections raised by the Mejlis, indicated that it understood Articles 5 and 6 as applying

only to cases in which preparations have been made for a considerable armed attack upon Russia or the Soviet Republics allied to her, by the partisans of the regime which has been overthrown or by its supporters among those foreign powers which are in a position to assist the enemies of the Workers and Peasants' Republics and at the same time to possess themselves, by force or by underhand methods, of part of the Persian territory, thereby establishing a base of operations for any attacks-made either directly or through the counter-revolutionary forces-which they might meditate against Russia or the Soviet Republics allied to her. ${ }^{19}$

The annex, which may be considered an integral part of the treaty, seems to introduce substantial limitations on the regime in Article 6 . The broad unilateral competence to characterize events as menacing, to assess, where pertinent, the adequacy of the Iranian response to a Soviet demand to terminate the offending activity and to decide when to withdraw, remains exclusively Russian. But the actual precipitating event is now stated with more precision than in Article 6: preparations for a "considerable armed attack" on socialist or allied territory by partisans or foreign power supporters of the defunct tsarist regime. As for the latter, the preparation must include acquisition of Iranian territory.

Hence, one line of interpretation suggests that the intervention contemplated by the treaty was limited to a most restricted set of circumstances. But, even as revised by the annex, Article 6 is a broad privilege; the vagueness of the conditions for intervention gives great discretion to the USSR, the only party authorized to implement it. Yet it is the beginning of a limitation and, given some of the changes in subsequent circumstances, the annex may now operate to defeat the treaty.

\section{III.}

If the 1921 treaty is read with the annex, it is quite probable that changes in circumstances provide the Iranian Government with strong grounds for termination. Article 62(1) of the Vienna Convention on the Law of Treaties " provides:

1. A fundamental change of circumstances which has occurred with regard to those existing at the time of the conclusion of a treaty, and which was not foreseen by the parties, may not be invoked as a ground for terminating or withdrawing from the treaty unless:

(a) the existence of those circumstances constituted an essential basis of the consent of the parties to be bound by the treaty; and

1. Id, at 411 .

UN Doc. A/CONF.39/27 (1969), reprinted in 63 AJIL 875 (1969), 8 ILM 679 (1969). 
(b) the effect of the change is radically to transform the extent of obligations still to be performed under the treaty.

The Soviet clarification of December 12,1921, indicates that its major concern was the possibility of activities by antirevolutionary groups that might use Iranian territory to mount attacks on Russia itself. Such a concern was realistic in 1921, for the USSR had just survived a brutal civil war and its domestic and international position was still parlous. Implementation of this concern through Article 6 of the treaty would have appeared reasonable in the context and, perhaps most important, of limited concein to Iran if the privilege in Article 6 were exercised in good faith. The fundamental circumstances that animated the 1921 treaty were Soviet domestic and international politics in the earliest and most unstable years after the Bolshevik Revolution.

Diehard anti-Soviet groups flourish in some parts of the world, if not in Iran, but even the most paranoid of Soviet security specialists can appreciate that the period of peril in 1921 is past. The Soviet Union is one of the giants of contemporary international politics. Moreover, the nature of warfare has changed and the importance of territorial propinquity has diminished. Indeed, one superpower has learned to live with its adversary's agent close by. Given the fundamental changes of circumstance, continuation of Article 6 of the Treaty of Friendship would, in the language of Article 62(1) of the Vienna Convention, "radically . . . transform the extent of obligations still to be performed under the treaty." A privilege, in its original context related to the most urgent matters of governmental survival, would in the new context be available for interventions that can no longer be related in any plausible manner to national self-preservation. In this new political context, Iran would be entitled to invoke fundamental change of circumstances as a ground for the termination of Article 6 of the treaty.

\section{IV.}

If the annexes of the 1921 treaty are ignored and the treaty is read primarily with the text of Article 6 in mind, its continuing validity must be scrutinized in the light of intervening international norms from which derogation is not permitted. Two, of post-1945 vintage, are of special importance. The first is Article 103 of the UN Charter: "In the event of a conflict between the obligations of the Members of the United Nations under the present Charter and their obligations under any other international agreement, their obligations under the present Charter shall prevail." Thus, a commitment, antedating or postdating the Charter, that is in conflict with a Charter obligation cannot be used to justify action in violation of the Charter. ${ }^{21}$ An effort by a party to the older agreement to enforce

21 Article 103 is much more than an application of the principle of lex postertor derogat priori. That principle is expressed in Article 59 of the Vienna Convention on the Law of Treaties; indeed it may, by its operation, effect termination of Article 6 of the 1921 treaty because of inconsistency with the UN Charter. Article 59 of the Vienna Con- 
it would be delictual after 1945 and might even be deemed a breach of the peace or act of aggression within the meaning of Charter Article 39.

A second exception to the continuity of agreement is the emergence of a new peremptory norm or jus cogens. Article 53 of the Vienna Convention on the Law of Treaties provides:

A treaty is void if, at the time of its conclusion, it conflicts with a peremptory norm of general international law. For the purposes of the present Convention, a peremptory norm of general international law is a norm accepted and recognized by the international community of States as a whole as a norm from which no derogation is permitted and which can be modified only by a subsequent norm of general international law having the same character.

Article 64 of the convention provides: "If a new peremptory norm of general law emerges, any existing treaty which is in conflict with that norm becomes void and terminates." Thus, a new peremptory norm may also defeat the intertemporal principle.

In 1921, at the time of its conclusion, the Soviet-Iranian Treaty of Friendship may well have been lawful. Though an incipient collective security system existed in the League of Nations, the Soviet Union was not party to it and, in the context, would have had scant reason to rely on it. Moreover, the League of Nations, as opposed to the United Nations, would not have prohibited per se the sort of interventionary rights envisaged in the 1921 treaty. Article 21 of the Covenant of the League provided that "[n]othing in this Covenant shall be deemed to affect the validity of international engagements, such as treaties of arbitration or regional understandings like the Monroe doctrine, for securing the maintenance of peace." Even in the absence of Article 21 or of questions about its applicability, it is probable that in the second decade of the century an otherwise lawful agreement would not have been invalidated because it granted discretionary rights of intervention to an outside state.

But in the period after 1945, there is substantial reason to doubt the continuing lawfulness of the regime contemplated in Article 6 of the Friendship Treaty. Article 2(4) of the UN Charter provides: "All Members shall refrain in their international relations from the threat or use

vention provides:

1. A treaty shall be considered as terminated if all the parties to it conclude a later treaty relating to the same subject-matter and:

(a) it appears from the later treaty or is otherwise established that the parties intended that the matter should be governed by that treaty; or

(b) the provisions of the later treaty are so far incompatible with those of the earlier one that the two treaties are not capable of being applied at the same time.

2. The earlier treaty shall be considered as only suspended in operation if it appears from the later treaty or is otherwise established that such was the intention of the parties.

Charter Article 103, in contrast, does not superordinate Charter obligations because of a temporal factor (most recent in time prevailing) but because of the legal superiority of those obligations with regard to any others. Hence it can override agreements concluded after 1945. 
of force against the territorial integrity or political independence of any state, or in any other manner inconsistent with the Purposes of the United Nations." However a use of force under Article 6 might be rationalized, it necessarily infringes the territorial integrity of the target, and insofar as it is not invited by that state in that particular instance, it impairs its political independence.

There is wide recognition of the fundamental quality of the norm expressed in Article 2(4) of the Charter. The International Law Commission's commentary on jus cogens remarks that "the law of the Charter concerning the prohibition of the use of force in itself conistitutes a conspicuous example of a rule in international law having the character of jus cogens." 22 The principle has been illuminated in a nurnber of provisions by the Declaration of Friendly Relations. ${ }^{23}$ Moreover, the collective security system established by the UN Charter and vesting primary competence in the Security Council ${ }^{24}$ for response to threats or breaches of

22 Official Records, UN Conference on the Law of Treates, Documents of the Conference 67, UN Doc. A/CONF.39/11/Add.2 (1971).

23 GA Res. 2625 (XXV), Oct. 24, 1970, 25 UN GAOR, Supp. (No. 28) 121 et seq. Pertinent provisions are:

The principle that States shall refrain in their international relations from the threat or use of force against the territorial integrity or political independence of any State, or in any other manner inconsistent with the purposes of the United Nations

Every State has the duty to refrain in its international relations from the threat or use of force against the territorial integrity or political independenie of any State, or in any other manner inconsistent with the purposes of the United Nations. Such a threat or use of force constitutes a violation of international law and the Charter of the United Nations and shall never be employed as a means of settling international issues. ...

Every State has the duty to refrain from the threat or use of force to violate the existing international boundaries of another State or as a means of solving international disputes, including territorial disputes and problems concerning frontiers of States.

The territory of a State shall not be the object of military occupation resulting from the use of force in contravention of the provisions of the Chirter. The territory of a State shall not be the object of acquisition by another State resulting from the threat or use of force. No territorial acquisition resulting from the threat or use of force shall be recognized as legal. ...

The parties to a dispute have the duty, in the event of failure to reach a solution by any one of the above peaceful means, to continue to seek a settlement of the dispute by other peaceful means agreed upon by them.

States parties to an international dispute, as well as other States, shall refrain from any action which may aggravate the situation so as to endanger the maintenance of international peace and security, and shall act in accordance with the purposes and principles of the United Nations.

No State or group of States has the right to intervene, directly of indirectly, for any reason whatever, in the internal or external affairs of any other State. Consequently, armed intervention and all other forms of interference or attempted threats against the personality of the State or against its political, economic and cultural elements, are in violation of international law.

24 Charter Art. 24. But compare "Uniting for Peace," Res. 377A (V), November 3, 1950; Certain Expenses of the United Nations (Article 17, Paragraph 2 of the Charter), [1962] ICJ REP. 151; Legal Consequences for States of the Continued Presence of South Africa in Namibia (South West Africa) Notwithstanding Security Council Resolution 276 (1970), [1971] ICJ REP. 4. 
the peace or acts of aggression would appear both to preempt and to render caducous the regime of Article 6 of the Friendship Treaty. Any other interpretation would invite stronger states to intervene "by treaty" in the affairs of relatively weaker states, a practice which would be utterly incompatible with the principles of the Charter.

Jus cogens and the principles of the United Nations Charter do not render invalid all bilateral defense agreements. The decisive issue is the ongoing participation of a government in decisions about prospective interventions in its territory. Thus, one may contrast the 1959 U.S.-Iranian Agreement of Cooperation with the 1921 Soviet-Iranian treaty. Article I of the 1959 agreement provides:

The Imperial Government of Iran is determined to resist aggression. In case of aggression against Iran, the Government of the United States of America, in accordance with the Constitution of the United States of America, will take such appropriate action, including the use of armed forces, as may be mutually agreed upon and as is envisaged in the Joint Resolution to Promote Peace and Stability in the Middle East, in order to assist the Government of Iran at its request [emphasis added].:25

The critical difference here is the condition of mutual agreement, which serves as a case-by-case protection against unauthorized intervention and renders each entry into Iran by the United States a response to an invitation by Iran. The Iranian termination of the 1959 treaty with the United States may provide a certain symmetry with termination of the Soviet treaty. But, in fact, the United States loses nothing, while Iran loses a potential deterrent factor.

Nor does jus cogens deprive the USSR or any other state of rights of self-defense or, where appropriate, of humanitarian intervention under international law. But those rights are different from the regime of Article 6 ; the contingencies are more sharply defined, authorized procedures often incorporate international institutions, and the justification for unilateral coercive action in the territory of another state must meet considerably more stringent tests. The rights acquired under Article 6 of the 1921 treaty do not survive innovations in international law after 1945.

VI.

Judge Hutcheson's "just opinion" of "lawminded nations and peoples" 26 may appear too diffuse a sanction, but no state yearns to be stigmatized as an international lawbreaker. General recognition that Articles 5 and 6 of the 1921 Soviet-Iranian Friendship Treaty are no longer valid and cannot be used to justify a unilateral Soviet intervention in Iran and that the Iranian termination is lawful can itself serve a deterrent function. The

$\therefore$ Agreement of Cooperation Between The Government of the United States of America and The Imperial Government of Iran, 1959, TIAS No. 4189, 10 UST 314, 327 UNTS 277.

46 Report and Decision of the Arbitrator in the Claim of Edward J. Ryan . . ., 32 AJIL 593, 613 (1938). 
effectiveness of the deterrence can be enhanced by authoritative clarification of the legal status of the controverted provision. Article 65 of the Vienna Convention on the Law of Treaties provides for a notification procedure by the party claiming a ground for termination, termination becoming effective, absent urgency, in no less than 3 months. If the other party should object, the Vienna Convention directs the parties to seek a solution through the means indicated in Article 33 of the UN Charter. Presumably, the policy expressed in Article 18 of the Vienna Convention-no more than an illumination of the general principle of bona fides-would preclude the Soviet Union from exercising the disputed right pending authoritative clarification. One hopes that Iranian authorities will act with dispatch and the Soviet Government with restraint and a spirit of cooperation to clarify a matter of international law on which regional and international peace may depend.

W. Mrchael Reisman ${ }^{\circ}$

${ }^{-}$Myres S. McDougal, Leon S. Lipson, Eugene V. Rostow, Oscar Schachter, and Firuz Kazemzadeh contributed useful comments and criticisms which are gratefully acknowledged. 